\title{
AN ETHNOSEMANTIC STUDY ON PESANTREN LEXICON AS AN EFFORT FOR CULTIVATING CHARACTER EDUCATION
}

\section{KAJIAN ETNOSEMANTIK DALAM LEKSIKON KEPESANTRENAN SEBAGAI UPAYA PENANAMAN PENDIDIKAN KARAKTER}

\author{
Elisa Nurul Laili, Sakhi Herwiana \\ Universitas Hasyim Asy'ari Tebuireng Jombang \\ Ponsel: 085691237846; Pos-el: elisa_nurullaili@yahoo.co.id, herwianas@gmail.com \\ Received on: 12 September 2019; Revised on: 4 Desember 2019; Approved on: 4 Desember 2019
}

DOI https://doi.org/10.26499/mab.v13i2.261

\begin{abstract}
Formal, informal and non-formal educations are major milestones of post-family care that concern with shaping the character of their students. One form of education which has always been the choice of the majority of parents is pesantren education. Tradition in pesantren is a miniature of community tradition that deserves to be called a community which certainly has a major influence on the mindset and behavior of the students and alumni. One of traditions is the usage of a typical pesantren lexicon. The pesantren lexicon is one of the indirect efforts in character-building education. As it is well known, the majority of students in pesantren have good character as one of the goal of education carried out in pesantren. The educational process in the context of a pedagogical social environment such as pesantren is very interesting to be studied further so that it can be carried out also in the scope of other formal, informal, and non-formal education. This research is conducted to study the pesantren lexicons as an effort to plant character education in pesantren. This research usees ethnolinguistics theory by applying descriptive qualitative design.
\end{abstract}

Keywords: lexicon; pesantren; ethnosemantics; character education

\begin{abstract}
Abstrak
Pendidikan sekolah, baik formal, informal maupun nonformal, merupakan tonggak utama pasca pengasuhan keluarga yang akan membentuk karakter anak didiknya. Salah satu bentuk pendidikan yang selalu menjadi pilihan mayoritas orangtua adalah pendidikan pesantren, adat dan budaya pesantren merupakan miniatur kebudayaan masyarakat yang layak disebut sebagai suatu komunitas, yang tentunya berpengaruh besar terhadap pola pikir serta perilaku para santri dan alumninya. Salah satunya, pembiasaan dan penggunaan leksikon khas pesantren. Leksikon kepesantrenan secara tidak langsung merupakan salah satu upaya dalam pendidikan pembentukan karakter. Sebagaimana yang telah diketahui, mayoritas santri akan memiliki sifat dan karakter yang baik, sebagai salah satu contoh keberhasilan pendidikan yang dilaksanakan di lingkup pesantren tersebut. Proses pendidikan dalam konteks lingkungan sosial pedagogis seperti halnya pesantren ini sangat menarik untuk dikaji lebih lanjut agar dapat dilaksanakan pula dalam lingkup pendidikan lainnya, baik formal, informal, maupun nonformal. Penelitian ini dilakukan untuk mengkaji leksikon kepesantrenan sebagai upaya penanaman pendidikan karakter. Penelitian ini menggunakan teori etnolinguistik. Penelitian dilaksanakan dengan metode deskriptif kualitatif.
\end{abstract}

Kata Kunci: leksikon; pesantren; etnosemantik; pendidikan karakter 


\section{Introduction}

Language is a cultural product and at the same time, a cultural delivery medium from the language community concerned. In cultural studies, language is placed as an important element in addition to other elements, such as knowledge systems, livelihoods, customs, arts, and living equipment systems. Language can be categorized as a cultural element in the form of nonmaterial in addition to values, norms, and beliefs (Liliweri in Mahsun, 2005:47). Mahsun (2005:81) states that language is a very important human culture. Through language, humans not only express their thoughts but also interpret and conceptualize the world that surrounds them.

Proof of the diversity of languages is the phenomenon of the use of language as a means of expressing the relationship between humans and the natural surroundings. Language in its use by the speech community is recorded from the sources of speech and correspondence that live around us. Speakers of any language have to know, master, and use lingual tools related to their environment, both the social and natural environment. From the perspective of cognitive anthropology, a set of lexicons used are objects, events, and signs of activity that are important in their environment (Casson, 1981). In many ways, what people think or feel is always realized by language. Therefore, the culture of a speech society always colors the language used. Likewise, what people think, feel, and due to their environment will be reflected in the language used (Mardikantoro, 2016:48).

In this study, the researcher seeks an ethnographic entity to be the subject of the study and the subject of the description. Clifton in Koentjaraningrat (2005:2) states that there are ten main locations and ethnographic points that can be described, namely:

1) Unity of the community bounded by one village or more than one village.

2) Unity of the community consisting of residents who speak one language or one dialect.

3) Unity of society bounded by administrative political boundaries.

4) Community unity whose limits are determined by a sense of the identity of its population.

5) Unity of the community determined by a geographical area which is a unitary physical area.

6) Community unity determined by ecological unity. 
7) Community unity with residents who have the same historical experience.

8) Community unity with a high frequency of interaction.

9) Unity of society with a uniform social structure.

10) Unity based on ethnic culture.

the researcher took the location of pesantren ${ }^{(1)}$ based on ethnographic points proposed by Clifton above, especially by following points $4,5,7,8$ and 9. Pesantren is by following principle number 4 because pesantren is a community unit or group of people whose sense of identity is determined by the students as residents. The identity of being santri of pesantren has certainly bound the sense of kinship and solidarity of santri $^{(2)}$ because they have the same alma mater. The identity will even carry over until they leave his pesantren. In other words, the identity will stick even though they have become alumni of pesantren.

To point 5 above, santri are a group of people, community, or society who live in a geographical area or in a single physical area, the location of pesantren. Sometimes pesantren are bounded by walls and gates that separate pesantren's environment from the surrounding villagers' houses.
However, some pesantren do not have such physical borders with villagers'. Nevertheless, santri usually understands the borders between the location of pesantren with the village or village residents.

Point 7 is also in line with pesantren ethnography. Santri who still lives and who has left pesantren (alumni) naturally have the same historical experience. History in recognizing the vision and mission of pesantren, history of the pesantren's establishment, the family line of pesantren or kyai caregivers, and the history of sanad and scientific councils that have been visited or studied by pesantren kyai (caregivers). Usually, these are the reasons for santri or their parents why they decide to go to pesantren and live there.

In line with point 8, pesantren can also be referred to a community unit with a high frequency of interaction. Considering that they live in a pesantren area for 24 hours and years by years, it is certain that their interaction patterns are quite high. The interaction of the students is manifested in various activities both formal (such as schools, obligatory prayers, reading classical books, and other mandatory activities) 
and informal (such as queuing for food, bathing, buying snacks, becoming on a duty assistant, and so on).

Next, point 9 which says 'the unity of society with a uniform social structure'. This is also in line with pesantren because santri are social representations of a diverse society in one religious framework. This is reflected in various activities carried out in Pesantrens, such as religious rituals on jamaah maktubah (obligatory prayers which is done in congregation), muhadhoroh (trial of doing formal speech in front of public), haflah akhirussanah (farewell party after finishing final examination, and also for graduation ceremony), bahtsul masa'il (forum discussion aimed to solve some actual problems which is viewed by the framework of religious matters) and ro'an (doing cleaning services activities surrounding pesantren area, including mosque, rooms, bathrooms, and caregiver's graveyard). The activity represented a small portion of the social diversity of the students. The students who came from different social backgrounds mingled to carry out various religious activities and rituals together and uniformly led by kyai (caregiver of pesantren).
Based on the above considerations, pesantren was chosen as the location of this study, because the main ethnography of which is interesting and relevant for further study and description. This is by following the challenges of the Indonesian people against the deterioration of the younger generation's character which is increasingly undermining the unity and integrity of Indonesia under the slogan of Bhineka Tunggal Ika (Unity in Diversity). Pesantrens are expected to be a solution to the nation's problems concerning character education.

the study investigated the use of the language lexicon used by students and the community within the pesantren. Language itself is one of the cognitive or abstract cultural products starting from the whole multilevel cognitive system, starting from the value system, progressing to the level of the system of relations or sociocultural construction in the form of civilization, and finally represented or realized at the third level as a human communication system in forms of habit or cultural identity (Mangkey, et al., 2010:59). 


\section{Theoretical Framework}

\subsection{Lexicon}

The term lexicon is commonly used to accommodate the concept of "collection of lexemes" of a language, both a collection as a whole or in part (Chaer, 2007:2-6). Meanwhile, in KBBI Offline: "the lexicon is a language component that contains all information about the meaning and usage of words in the language."

Furthermore, Sibarani (1997:4) slightly distinguishes the lexicon from the vocabulary, that is, the lexicon includes components that contain all information about words in a language such as semantic, syntactic, morphological, and phonological behavior, whereas vocabulary is emphasized more on the wealth of words owned by a person or a language. Meanwhile, (Kridalaksana, 2007:127), argues that the lexicon can be divided into two, namely the active lexicon and the passive lexicon. An active lexicon is the wealth of words used by someone. A passive lexicon is a wealth of words understood by someone who has never or rarely used.

Boas in Palmer (1999:11) says that language is the most important manifestation of the speaker's mental life.
Furthermore, the results of Boaz's observation show that language underlies the classification of experience so that various languages classify experiences differently and such classifications are not always realized by their speakers.

\subsection{Culture and Local Wisdom}

According to Lévi-Strauss (2001:146), culture (culture): the whole complex of knowledge and behavior, involving science, beliefs, arts, morals, law, customs and all other intellectual properties learned by humans as members of a particular society and are passed down from one generation to another. Furthermore, culture must be viewed in the context of communication theory as a whole system (language, kinship, economy, myth, art) which at various levels enables and regulates human communication. Furthermore, Salzmann (1993:271) argues:

"The complex of human learned behavior, knowledge, and beliefs transmitted from one generation to the next. Culture is the pattern of learned behavior, knowledge, and beliefs transmitted from one generation to generation by members of a particular society."

Culture is the identity of a nation that can distinguish one nation from another nation. Every part of culture must have local wisdom values in it. As 
said by Sibarani (2014:114) Local wisdom is the wisdom of original knowledge of a society derived from the noble value of cultural traditions to regulate the order of people's lives. Local wisdom is a local cultural value that can be used to regulate the order of people's lives wisely or wisely.

Sibarani (2014:121-135) also states that local wisdom is often considered the equivalent of the word 'indigenous knowledge', namely habits, knowledge, perceptions, norms, and culture that are shared with a community (local) and hereditary life. Local wisdom is a human property that originates from its cultural values by using all of its mind, mind, heart, and knowledge to act and behave towards the natural environment and social environment. The types of local wisdom according to Sibarani are welfare, hard work, discipline, education, health, cooperation, gender management, preservation, and cultural creativity, caring for the environment, peace, politeness, honesty, social solidarity, harmony and conflict resolution, commitment, thoughts, thoughts positive, and thankfulness.

Sibarani (2014:59) says that cultural values that can be conveyed by language as a cultural successor pathway are divided into three interrelated parts of culture, namely expression culture, traditional culture, and physical culture. Cultural expression includes feelings, intuition beliefs, ideas, and collective imagination, traditional culture includes religious values, customs, and habits, physical culture includes the results of original works that are utilized by society in everyday life.

Politeness and and some positive characteristics of students are the result of the education process and also a product of the culture of the pesantren so that it can also be said to be part of the culture in a society. Therefore, in some Pesantren lexicons contained local wisdom derived from the cultural values of the Pesantren (santri) community. In some pesantren lexicons some local wisdom will be found because in carrying out some parts of this pesantren community culture, the lexicon used daily in santri communication plays an important role in shaping the character of santri.

\subsection{Pesantren and Character} Education

The institutionalized Pesantren in the community, especially in the countryside is one of the oldest Islamic educational institutions in Indonesia. The initial presence of pesantren is traditional to explore the Islamic religious sciences 
as a way of life in society (Mastuhu in Syafei, 2017:62). Because of its uniqueness, C. Geertz, as well as Abdurrahman Wahid called it a subculture of Indonesian people (especially Java). During the colonial era, pesantren became the basis of the struggle of the nationalist-indigenous person (Syafei, 2017:62).

Pesantren educational institution in the form of a boarding school which is a separate community under the leadership of the kyai or ulama is assisted by one or several scholars, and or religious teachers who live together among the students with a mosque or mosque as the center of religious worship activities. Also besides, school buildings or study rooms are the centers of teaching and learning activities, and the huts are places for students to live. For 24 hours, from time to time they lived collectively between clerics, religious teachers, santri and other pesantren caregivers, as one big family (Hayati via Syafei, 2017:62).

Character education has a higher meaning than moral education, because character education teaches students not only being able to distinguish what is right and what is wrong, more than that character education instills values through habits about good things so students become understanding (domain cognitive) about which is good and wrong, able to feel (affective domain) good value and usually do it (behavioral domain) (Ministry of National Education in Nizarani, 2019:1137).

to character education, Lickona argues that the process of character education emphasizes the three components of good character, namely moral knowing, moral feeling, and moral action. In the context of the character education process in the pesantren, the stages of moral knowledge are conveyed in the dimension of the mosque and the dimension of the community by the kiai and the cleric. The moral feeling is developed through the direct experience of the students in social and personal contexts. Emotional aspects emphasized for students to feel include the nine pillars of character education, especially the pillars of God's love and all of its creations. While moral action includes every pesantren effort to make the pillars of the character education of God's love and all of its creations manifested into concrete actions. This was realized through a series of habituation programs to do good deeds according to the 
parameters of Islam in pesantren environment (Afifudin, 2016:33).

In realizing moral action, pesantren pay attention to three other aspects related to the efforts to embody educational material to be a character in the students themselves, these three aspects include competencies, desires, and habits. The formation of the three aspects was pursued by the chaplain in an integrated and consistent manner which in the end was expected to give birth to moral actions (moral actions) which were spontaneously carried out by children, both in the pesantren, family, and community circles (Afifudin, 2016:3334).

According to Megawangi there are nine character values that should be taught to students in the context of character education, namely, (1) God's love and all of His creations; (2) independence and responsibility; (3) honesty and trustworthy, wise; (4) respect and courtesy, (5) generous, helpful, and mutual cooperation; (6) confident, creative, hard-working; (7) leadership and justice; (8) kind and humble; (9) tolerance, peace and unity. Lickona added ten essential virtues needed to form good character. The ten essential virtues are wisdom, justice, fortitude, self-control, love, positive attitude, hard work, integrity, gratitude, and humility (Fahham, 2013:32).

Curriculum Center of the Ministry of National Education (2011:9-10) identified 18 values derived from religion, Pancasila, culture, and national education goals that can be referred to as character buildings, namely: (1) religious, (2) honest, (3) ) tolerance, (4) discipline, (5) hard work, (6) creative, (7) independent, democratic, (9) curiosity, (10) national spirit, (11) patriotism, ( 12) reward achievement, (13) communicative, (14) peace-loving, (15) fond of reading, (16) caring for the environment, (17) caring socially, and (18) responsibility.

\section{Research Method}

the ethnolinguistic approach is used to explain the culture that exists in modern and traditional pesantren, while the structural approach is used to analyze the language used by the local environment to express local culture. This research is qualitative. According to Bogdan and Taylor in Moleong (1991:3), qualitative research is a research procedure that produces descriptive data in the form of written data and oral data from people or the community and their behavior can be observed from the natural environment. 
The method of providing data in this study is observation, library research, and documentation (Mahsun, 2005:92, Kesuma, 2007:43). The basic technique used by researchers is the technique of note-taking, categorizing and classifying the data obtained (Mahsun, 2007:133). Also besides, researchers use participatory observation methods. The researchers conducted observations, taking notes, and documented the data. The key method applied in such activities is participatory observation, which is participating in activities that are observed, described, and analyzed (Sibarani, 2014:54). In interpreting the data, researchers use content analysis techniques or content studies. The analysis used is descriptive language analysis according to the socio-cultural aspects of the speech community (the scope of pesantren).

The research is done in Hasyim Asy'ari University from the first week of March until the end of August 2019. 50 students of this university from the first year up to the third year are as respondents of this research. The researchers interviewed and observed them as santri, because they live in pesantren surrounded Hasyim Asy'ari University. The name of pesantren they lived are Ma'had al-Jami'ah Hasyim Asy'ari, PP. Tebuireng Putra, PP. Tebuireng Putri, PP. Seblak, PP. Darul Falah, PP. Walisongo, PP.Al-Aqobah, PP. Al-Mahfudz, PP. Paculgowang, and PP Darul Ilmi wal Fikri. Those pesantren are located in Jombang, East Java Indonesia.

The primary data are taken from observation, interviewing and taking notes from santri's activities. Besides, the first researcher is also alumni of pesantren, so she is able to understand and insert some related lexicons she got from her pesantren. The researchers also took secondary data from Salafy dictionary that becomes the reference of santri to give or interpret meanings on classical books. The researchers then triangulate those data obtained to teachers or ustaz who also alumni of pesantren.

\section{Findings and Discussion}

Based on research that has been done, there are two types of lexicons used in the scope of pesantren, namely words and phrases. The lingual form in the form of words can be explained by following the classification of the lexicon. There are 11 groups of lexicon based on the classification that has been 
done, namely the daily object lexicon, worship, learning, greeting, place, activity, good characters, bad characters, diseases, human body parts, and animals.

It cannot be denied, pesantren is an important part of informal educational institutions from time to time that is trusty in shaping the character of students. This role is not separated from several aspects. First, role models of students. Secondly, the pesantren curriculum designed by pesantren caregivers always prioritizes morals from an early age (becoming a provision for character theory). Third, the environment and zone of friendship in pesantren which always form positive character (becomes the practice of character theory). Fourth, the pesantren culture that forms positive rules and norms. Fifth, the language used reflects sincerity or politeness through oral or written language. Those aspects are closely related to the use of pesantren lexicons in santri's daily life through conversation and meaning interpretation of classical books they learned.

First, role models or role models of students. Role Model of the students is the most influential figure in shaping the character of the students. Kyai, Bu Nyai, Ustadz/ah, Murobbi/ah, Gus,
Ning, and dzurriyah will become an ideal role model both in terms of speech, fashion, attitude, and behavior. Through the use of greeting lexicon, the philosophical value of the word will be even higher because it contains an element of morality that must be upheld, both in terms of respect from the students, speech, clothing, attitudes, and behavior of each of the lexicons used.

In daily expressions, students also use a greeting lexicon that is close to the person's profession, for example khodimah (servant), ustadz/ah (teacher), murobbi/ah (guardian of dormitory) and musyrif/ah (fellow who is more senior who has duty for accompany santri). Greetings to those professions socially contain higher philosophical values. The use of those lexicons make the profession more sacred because of social stratification within the pesantren, the profession of khodimah, ustadz/ah, murobbi/ah and musyrif/ah are above santri level.

Second, the pesantren
curriculum designed by pesantren
caregivers which always prioritizing
morals from an early age. Lessons or
material studied in Pesantrens are
curricula that have been set by
caregivers. The first and foremost
material reviewed is the book about
182 | Mabasan, Vol. 13, No. 2, Desember 2019, hlm. 173-188 p-ISSN: 2085-9554, e-ISSN: 2621-2005 
morals. There are various moral books that have been studied in pesantren environment, those titles are alala, washoya, akhlaq lil banat, akhlaq lil banin, ta'limul muta'alim, taysirul kholaq, adabul 'alim wal muta'alim, tanbihul ghofilin, al-hikam, 'izzul adab, 'idzotun nasyi’in, al-mar'atus sholihah, and so on.

In these books, almost all lexicons of good and bad character are explained. These books explain how a human being is said to be a human being if he has a commendable character (akhlak mahmudah) detailed by deep explanation. While the explanation of bad traits / characters makes humans avoid these traits so as not to be referred to as human beings who have despicable traits (akhlak madzmumah).

Based on the data above, the lexicon of good and bad characters is very numerous and varied. This shows that the pesantren curriculum related to morals is strongly emphasized and repeated in various moral lessons so that it can be applied by the students after studying or studying the books. Even the students also use the lexicon in daily communication. Because the use of good and bad traits of good and bad characters consciously and unconsciously (in daily conversation) is engraved in students' cognition, their character is formed which then manifests in the implementation of daily actions or behavior.

In some lexicons, good and bad characters have similar meanings. For example, the reflection of good character contained in the lexicon of good character for examples tawadhu', andhap asor, merkungkung, and ngesorake lambung has almost the same meaning, which is humble or modest. Lobo and loman have the same meaning which is generous. A reflection of the disgraceful morals contained in the bad character lexicon, for example, gumedhe, kemungklung and kumaluhur has the same meaning, which is arrogant. Cethil, kumet and medhit has the same meaning, which is stingy or miserly.

The character values taught in the pesantren morals are in line with the character values mentioned by Megawangi and Lickona in Fahham (2013), namely the love of God and all of His creations; independence and responsibility; honesty and trustworthy, wise; respectful and polite, generous, helpful, and mutual cooperation; confident, creative, hard work; leadership and justice; kind and humble; tolerance, 
peace and unity, wisdom, fortitude, selfcontrol, love, positive attitude, integrity, gratitude, and humility.

Third, the environment and zone of friendship in pesantren which always form positive character. The climate of friendship in pesantren is the manifestation or manifestation of most of the character values that have been instilled through moral lessons. These character values are also in line with a several some many tolerance character values expressed by the Curriculum Center of the Ministry of National Education (2011), namely: tolerance, democracy, national spirit, love of the motherland, friendly/communicative, peace-loving, environmental care, and social care.

Santri comes from various ethnic groups and regions from all over Indonesia. With an environment that brings them together in pesantren, it will certainly foster values of tolerance, friendship/communication, love for peace and love for the motherland. The various activities that they do ranging from getting out of bed to going back to sleep will always blend in with the diverse pesantren community. Even some activities are specifically designed to foster a spirit of nationalism and love for the country, for example, the concept of haflah akhirussanah which brings the theme of Bhineka Tunggal Ika, regional traditional dance performances to start the event muhadhoroh, and so forth.

Because they already know the variety of cultures and languages of various tribes and regions through their friends, there arises a sense of tolerance, democratic and friendly/communicative. All activities are carried out based on the principles of tolerance and democracy. Through this togetherness also gave birth to a sense of concern for the environment and society as evidenced by the holding ro'an activities in pesantren and surrounding environment as well as social service activities aimed at the community, especially those in need. In fact, in the Tebuireng Pesantren, the supporting institutions were formed, 'Bank Sampah Tebuireng' and 'Lembaga Sosial Pesantren Tebuireng'.

Fourth, the pesantren culture that forms positive rules and norms. The high intensity of activities and interactions in Pesantrens forms structured cultural patterns. As revealed by Koentjaraningrat that society is a unity of human life that interacts according to a system of customs that is continuous and bound by a sense of shared identity (1990:146-147). Poerwadarminta (1976:636) states that 
society is a living association, a group of people who live together in a place with certainties or rules. So students living in pesantren can be said to be a community unit that has certainties, who live together to interact in a continuous rule.

Viewed from Koentjaraningrat's ideas about three cultural forms (1990:186), (1) a complex of ideas, ideals, norms, values, rules and so on; this form resides in the minds of the community members or it can also be in the form of writings, essays by the community members concerned, (2) a complex pattern of behavioral activities from humans in the community; this form is a social system in the society concerned, (3) objects created by human beings; it is in the form of tangible physical culture which is the work of the people concerned. Then it can be concluded that norms, values, and regulations within pesantren environment are a form of pesantren community culture.

The rules applied in the pesantren environment can be seen from the representations contained in several lexicons, such as ta'zir, satir, and jamaah maktubah. Ta'zir can occur if a santri violates pesantren rules. Lexicon satir is a limitation that male and female students in a number of activities should not be mixed. While jamaah maktubah establish mandatory rules that the five daily obligatory prayers must be held in a congregation, if not met then it will get ta'zir.

Fifth, the language use which reflecting sincerity or politeness through oral or written. Santri language used in pesantren is always filled with politeness and positive character reflection. It can be seen from the variety and variety of good and bad character lexicon, as well as a very thick activity lexicon with positive character planting nuances. The lexicon is not only used daily but is also used in various pesantren lessons and scientific studies contained in the yellow books that are studied by the students.

The politeness of santri language through oral is reflected in the use of Javanese Krama Madya when communicating with senior or seniorlevel or who you are called with Kang/Mbak. While the use of Javanese Krama Inggil santri is more used when communicating with teachers (ustadz/ah, murobbi/ah, musyrif/ah) and Kyai/Bu Nyai, dzurriyah pesantren, son/daughter Kyai (gus and ning), new 
people, as well as people who are older and respected. The use of Javanese Ngoko only used when students communicate with very close friend or to juniors who are also very close.

While the politeness of language through writing can be seen from various posters or banners that contain prohibitions, invitations, appeals, or orders to do something positive, but by using very polite language. The use of language in posters and banners usually also takes the proverbs and sayings that are relevant to the prohibition, invitation, appeal or order to do something. Because it is polite and universal, the languages that are often used are Indonesian, Arabic and sometimes also translated into English.

\section{Closing}

Based on research that has been done, there are two types of the lexicon used in the scope of pesantren, namely words and phrases. The lingual form in the form of words can be explained by following the classification of the lexicon. There are 11 groups of lexicon based on the classification that has been done, namely the object lexicon, worship, learning, greeting, place, activity, good character, bad character, disease, limbs, and animals.
Pesantren becomes one informal educational institution which are reliable and trustworthy from time to time that in shaping the character of santri or students. It is not separated from some aspects. First, uswatun hasanah or role models of students. Secondly, the pesantren curriculum designed by pesantren caregivers always prioritizes morals from an early age (becoming a provision for character theory). Third, the environment and climate of friendship in pesantren which always form positive character (becomes the provision of the practice of character theory). Fourth, the pesantren culture that forms positive rules and norms. Fifth, the language used reflects sincerity or politeness through oral or written.

\section{References}

Afifudin. 2016. "Pendidikan Karakter Berbasis Al-Qur'an: Penerapan Pola Sistematika Nuzulnya Wahyu Di Pondok Pesantren Hidayatullah Panyula Kabupaten Bone." Dalam Jurnal Lentera Pendidikan, Vol. 19 No. 1. hal: $30-41$.

Casson, R.W (Ed.) 1981. Language, Culture, and Cognition: Anthropological 
Perspectives. New York: Macmillian Publishing Co.Inc.

Chaer, Abdul. 2010. Sosiolinguistik.

Perkenalan Awal. Jakarta: Rineka Cipta.

Fahham, A. Muchaddam. 2013. "Pendidikan Karakter di Pesantren" dalam Jurnal Aspirasi, Vol.4 No. 1, hal: 29-45.

Kementerian Pendidikan Nasional. 2011.

Pedoman Pelaksanaan Pendidikan

Karakter: Berdasarkan Pengalaman di

Satuan Pendidikan Rintisan. Jakarta:

Badan Penelitian dan Pengembangan

Pusat Kurikulum dan Perbukuan.

Kesuma, Tri Matoyo Jati. 2007. Pengantar (Metode) Penelitian Bahasa.

Yogyakarta: Carasvatibooks.

Koentjaraningrat. 1990. Sejarah Teori Antropologi. Jakarta: Penerbit Universitas Indonesia.

Koentjaraningrat. 2005. Pengantar Antropologi II: Pokok-pokok Etnografi. Jakarta: Rineka Cipta.

Kridalaksana, Harimurti. 2007. Pembentukan Kata dalam Bahasa Indonesia. Jakarta: Gramedia Pustaka Utama.

Lévi-Strauss, Claude. 2001. Mitos, Dukun dan Sihir. Terjemahan Cremers dan De Santo. Jakarta: Kanisius.
Mahsun. 2005. Metode Penelitian Bahasa: Tahapan Strategi, Metode dan Tekniknya. Jakarta: Raja Grafindo Persada.

Mahsun. 2005. Konsep Ruang dalam Bahasa Mbojo dan Kaitannya dengan Cara Pandang Masyarakat Penuturnya. Jurnal Linguistik Indonesia, 23(1), Februari 2005, hlm. 81-88.

Mangkey, Stanislaus, dkk. 2010. "Kebudayaan Minahasa: Kajian Etnolinguistik tentang Konstruk Nilai Budaya Lokal Menghadapi Persaingan Global" dalam jurnal Interlingua. Vol 4, April 2010. Hal. 56-77.

Mardikantoro, Hari Bakti. 2016. "Satuan Lingual Pengungkap Kearifan Lokal Dalam Pelestarian Lingkungan" dalam jurnal Bahasa Dan Seni, Tahun 44. Nomor 1. Hal 47-59.

Mbete, A. M. 2004. "Linguistik Kebudayaan: Rintisan Konsep dan Beberapa Aspek Kajiannya”, dalam Bawa, I.W. dan Cika, I.W (ed.), Bahasa dalam Perspektif Kebudayaan, halaman 16-32. Denpasar: Penerbit Universitas Udayana.

Moleong, Lexy J. 2000. Metodologi Penelitian Kualitatif, Bandung: Remaja Radikarya. 
Nizarani. 2019. "Manajemen Pendidikan Karakter Sekolah Islam Terpadu Berbasis Pesantren" dalam Prosiding Seminar Nasional Pendidikan Program Pascasarjana Universitas PGRI Palembang. Hal 1134-1147.

Palmer, G. B. 1996. Toward a Theory of Cultural Linguistics. Austin: University of Texas Press.

Poerwadarminta W.J.S. 1976. Kamus Umum Bahasa Indonesia. Jakarta: Balai Pustaka.
Salzmann, Z. 1993. Language, Culture, and Society: an Introduction to Linguistic Anthropology. Summertown: Westview Press Inc.

Sibarani, Robert. 2014. Kearifan Lokal. Medan: Asosiasi Tradisi Lisan.

Syafei, Imam. 2017. "Pondok Pesantren: Lembaga Pendidikan Pembentukan Karakter" dalam Al-Tadzkiyyah: Jurnal Pendidikan Islam. Volume 8, No I. hal: 6182.

[1] Pesantren is educational Islamic institution whose students learn classical books, Holy Quran, and many sharia prayers. They live in the dormitory for several days, doing many activities and routines scheduled by the principals.

[2] Santri are a term to name an individual or a group of students who live in Pesantren day and night for several continuously time. Sometimes they live months up to years to learn Islamic teachings in a comprehensively structured schedule. 